\title{
Interview with AK Thompson
}

\author{
E. Colin Ruggero ${ }^{1}$
}

[Article copies available for a fee from The Transformative Studies Institute. E-mail address: journal@transformativestudies.org Website: http://www.transformativestudies.org (C2021 by The Transformative Studies Institute. All rights reserved.]

ECR: This special section's title, "Revisiting the Riot," reflects my interest in bringing together contributions that examine the present through the lens of arguments you advanced a decade ago in Black Bloc, White Riot. My own re-reading of Black Bloc, White Riot brought a number of contemporary issues into sharp focus, and I think the book is as relevant now as it was when it was first published, perhaps even more so. I imagine it has been an interesting experience for you to reflect on the book against the backdrop of changes that have arisen in the social movement landscape over the past decade.

AKT: Black Bloc, White Riot came out in the summer of 2010, nearly ten years after the highpoint of the anti-globalization movement. At the time, I was preparing to defend my dissertation, which concerned the problem of social movement Romanticism, and my roommates had just been arrested on conspiracy charges related to their involvement in

\footnotetext{
${ }^{1}$ E. Colin Ruggero, Ph.D., is an Assistant Professor of Sociology at the Community College of Philadelphia. Colin received his Ph.D. from the New School in 2017 and his dissertation documented Occupy Philadelphia's interrelationship with the city's prefigurative, neoanarchist 'radical-DIY' political subculture. His more recent work examines dynamics of temporal coordination and orientation in movements, which will appear in an upcoming special issue of Social Movement Studies, in an article titled "Temporal Blindspots in Occupy Philadelphia," co-authored with Robin Wagner-Pacifici. Address correspondence to: E. Colin Ruggero, Community College of Philadelphia, Department of Sociology, Philadelphia, Pennsylvania; e-mail: eruggero@ccp.edu. AK Thompson is an activist, author, and social theorist. His publications include Spontaneous Combustion: The Eros Effect and Global Revolution (2017), Sociology for Changing the World: Social Movements/Social Research (2006), and coedited Keywords for Radicals: The Contested Vocabulary of Late-Capitalist Struggle (2016).
} 